\title{
Physicochemical and antioxidant composition of fresh peach palm (Bactris gasipaes Kunth) fruits in Costa Rica
}

\author{
Composição físico-química de frutos de pupunha (Bactris gasipaes Kunth) \\ na Costa Rica
}

\author{
Carolina Rojas-Garbanzo ${ }^{1 *}$, Ana Mercedes Pérez¹, Fabrice Vaillant ${ }^{2}$, María Lourdes Pineda-Castro ${ }^{3}$ \\ 1 Universidad de Costa Rica (UCR), Centro Nacional de Ciencia y Tecnología de Alimentos (CITA), Montes de Oca, San José - Costa Rica \\ ${ }^{2}$ Centre de Coopération Internationale en Recherche Agronomique pour le Développement (CIRAD-PERSYST), Montpellier - France \\ ${ }^{3}$ Universidad de Costa Rica, Escuela de Tecnología de Alimentos, Montes de Oca, San José - Costa Rica
}

\section{*Corresponding Author}

Carolina Rojas-Garbanzo, Universidad de Costa Rica (UCR), Centro Nacional de Ciencia y Tecnología de Alimentos (CITA), Apartado Postal: 11501-2060, Montes de Oca, San José - Costa Rica, e-mail: carolina.rojasgarbanzo@ucr.ac.cr

Cite as: Physicochemical and antioxidant composition of fresh peach palm (Bactris gasipaes Kunth) fruits in Costa Rica. Braz. J. Food Technol., v. 19, e2015097, 2016.

\section{Summary}

The variability of the physicochemical composition, carotenoid and polyphenol contents and hydrophilic antioxidant capacity of fresh peach palm (Bactris gasipaes) fruit was studied with a view to its exploitation as a potential source of bioactive compounds. The variability present in five batches of peach palm fruit obtained from two regions in Costa Rica: Tucurrique (T) and Pérez Zeledón (PZ), was studied. Significant differences were found for fruit weight, length and width amongst the batches studied. The moisture, fat and protein contents of the Tucurrique fruit were significantly lower than those from Pérez Zeledón. No significant difference in starch content was found between any of the batches of peach palm fruit studied. In terms of antioxidant compounds, the total carotenoid content ranged between 109 and $202 \mu \mathrm{g} \beta$-carotene equivalents $/ g$ dry weight (dw), while the total polyphenol content varied from 54 to $106 \mathrm{mg}$ gallic acid equivalents (GAE) /100 g (dw). Both these components presented variability amongst the five batches. The antioxidant capacity was determined by the ORAC method and only the PZ 3 sample presented significant differences from the other four batches. The average hydrophilic antioxidant capacity was $37 \pm 7 \mu \mathrm{mol}$ of Trolox equivalents $(\mathrm{TE}) / \mathrm{g}(\mathrm{dw})$. Overall, the peach palm fruit showed potential to be used in the development of functional foods since the variability of the raw peach-palm fruit, determined by applying a principal component analysis, showed that some characteristics of this fruit were not affected by harvest time and showed no differences between the batches from the two areas.

Keywords: Carotenoids; Polyphenols; Antioxidant capacity; Principal component analysis; Functional foods; ORAC.

\section{Resumo}

A variabilidade da composição físico-química e do teor de carotenoides e polifenóis, e a capacidade antioxidante hidrofílica da fruta fresca da pupunha (Bactris gasipaes) foram pesquisadas, a fim de avaliar o seu aproveitamento como uma fonte potencial de compostos bioativos. Estudou-se a variabilidade de cinco lotes de frutos da Costa Rica das regiões Tucurrique (T) e Pérez Zeledón (PZ). Foram encontradas diferenças significativas para a massa, o comprimento e a largura entre os lotes. Os teores de umidade, gordura e proteína dos frutos de Tucurrique foram significativamente menores do que os teores dos frutos de Pérez Zeledón. Não foi encontrada diferença significativa para o teor de amido entre todos os lotes de pupunheira estudados. Para os compostos antioxidantes, o teor de carotenoides totais variou entre 109 e $202 \mathrm{mg}$ equivalentes $\beta$-caroteno / g de matéria seca (ms), enquanto o teor de polifenóis totais variou no intervalo de 54 a $106 \mathrm{mg}$ de equivalentes de ácido gálico (GAE) / $100 \mathrm{~g}$ (ms). Ambos os compostos antioxidantes apresentaram variabilidade entre os cinco lotes. A capacidade antioxidante foi determinada pelo método ORAC e só a amostra PZ-3 foi significativamente diferente dos outros 
quatro lotes. A média da capacidade antioxidante hidrofílica foi de $37 \pm 7$ mmol de equivalentes de Trolox (TE) / g (ms). No geral, a fruta da pupunha apresenta potencial de utilização como ingrediente no desenvolvimento de alimentos funcionais, uma vez que a variabilidade da fruta da pupunha como matéria-prima, determinada pela aplicação de uma análise de componente principal, demonstrou que algumas das características dessa fruta não foram afetadas durante a época de colheita, e nenhuma diferença foi encontrada entre os lotes das duas áreas de estudo.

Palavras-chave: Carotenoides; Polifenóis; Capacidade antioxidante; Análise de componente principal; Alimentos funcionais; ORAC.

\section{Introduction}

Peach palm (Bactris gasipaes) is native to the Amazonian region and is adapted to a wide range of ecological conditions in the humid tropical regions. The crop extends from Honduras to Brazil, Bolivia and certain Caribbean islands (TRACY, 1996). The fruit of the peach palm has been a major staple food of native populations since pre-Colombian times (TRACY, 1996). Currently the peach palm fruit is still consumed in rural and urban areas of tropical America, and is also exported to ethnic markets in the USA (ROJAS-GARBANZO et al., 2011). The trees are palms, with trunks that can reach more than 20-30 $\mathrm{m}$ in height and $15-30 \mathrm{~cm}$ in diameter. The number of racemes per tree can vary from 10-25 and may exceed 35 (MORA-URPÍ et al., 1997). The variable parameters, including origin, climate, soil conditions and harvest time, can cause significant variation in the form, size, color and composition of the fruit (MORA-URPÍ et al., 1997).

Several studies have reported that the important nutritional components of this fruit are fat, starch and fiber, as well as a high energetic value (LETERME et al., 2005). The fruit is an attractive alternative due to its relevant antioxidant content, such as carotenoids (especially $\beta$-carotene), vitamin C, selenium and zinc (TRACY, 1996), and, as recently reported, polyphenols (CONTRERAS-CALDERÓN et al., 2011; DUTRA et al., 2012). Its contribution to the provitamin $A$ value is very important, since vitamin A deficiency is related to eye, skin and dental diseases (DIBARI, 1997), and Rojas-Garbanzo et al. (2011) reported that the fruit contributed at least $50 \%$ of the daily recommended intake with a minimum consumption of $100 \mathrm{~g}$ of cooked peach palm fruit.

The presence of bioactive compounds in peach palm fruit makes its consumption attractive due to the association of these compounds with a lower incidence of certain cancers and heart diseases (SÁ; RODRÍGUEZ-AMAYA, 2003). Antioxidant compounds can protect molecules such as lipids, DNA and proteins in the body from oxidative attack (PÉREZ-MATEOS et al., 2005). Considering these properties, consumers should follow the recommendation of increasing the consumption of fruits and vegetables rich in antioxidant compounds (ABUSHITA et al., 2000).

New initiatives in agro-forestry are also intended to alleviate poverty, protect the environment, and improve human well-being by integrating indigenous crops into industrial systems. This integration aims to meet people's needs for food and nutritional security (LETERME et al., 2005). This approach demands increased knowledge of the nutritional quality of fruits such as peach palm and its products. Although the physicochemical characteristics of peach palm fruit have been described previously, the characterization should be expanded to include the content of bioactive compounds such as carotenoids and fibre that distinguish this fruit as a functional food. These findings should be complemented with the determination of the antioxidant capacity and its value as a functional raw material for industrial use.

On the other hand, consumers and the agribusiness sector are interested in fruit quality, but variability of the fruit becomes important when process standardization includes the quality of the raw material. This study was undertaken to determine the physicochemical composition of fresh peach palm fruit with a view to its use in the agro industrial sector. The content of antioxidant compounds such as carotenoids and polyphenols was studied, as was its hydrophilic antioxidant capacity. Finally, the nutritional and functional value of peach palm fruit as a raw material for the development of industrial products was evaluated.

\section{Materials and methods}

\subsection{Raw material}

Two $60 \mathrm{~kg}$ batches of fruit were harvested in Tucurrique (Centro Agrícola Cantonal, 951'02.05"N, 8393'04.11"O, altitude $775 \mathrm{~m}$ ) and three batches in Tambor de San Pedro, Pérez Zeledón (9¹0'49.72”N, 8333'29.67"O, altitude $536 \mathrm{~m}$ ); both of these regions being located in Costa Rica. All of the batches were composed of fruit from a random selection of different palms and racemes growing in a plantation. The fruits were selected by colour (orange or red), ensuring that each fruit was free of both surface damage and microbiological deterioration.

\subsection{Sample preparation}

Each batch was washed and disinfected with a solution of 100 ppm of sodium hypochlorite ( $\mathrm{NaClO}$ ) for 15 minutes. The fruits were peeled and deseeded manually, and then homogenized, after which the moisture, fat and carotenoid contents were determined. The homogenized samples were vacuum-packed in aluminum foil bags 
and frozen at $-20{ }^{\circ} \mathrm{C}$ to prevent deterioration before the respective protein and starch analyses. The samples were then freeze dried for the polyphenol and antioxidant capacity analyses.

\subsection{Physicochemical analysis}

\subsubsection{Physical characteristics}

The weight and size (length and width) of the peach palm fruits were determined by measuring 40 individual fruits from each composite sample. The weight was determined using a digital balance, model GX-2000 (A\&D Weighing, Milpitas, CA, USA), and the size was determined by measuring the equatorial and longitudinal diameters with a vernier-type calliper (General Tools \& Instruments Co., LLC, New York, USA).

The colour was determined with a Hunter Lab colorimeter $\left(2^{\circ}\right.$ standard observer angle and illuminant C; Hunter Associates Laboratory Inc, Reston, VA, USA) and expressed as the $L^{*}, a^{*}$ and $b^{*}$ values. The parameters of hue $\left(h^{*}\right)$, chroma $\left(c^{*}\right)$ and total colour difference $\left(\Delta \mathrm{E}^{*}\right)$ were obtained as described by Gonnet (1998), using Equations 1, 2 and 3.

$$
\begin{aligned}
& \mathrm{h}=\tan ^{-1}\left(\mathrm{~b}^{*} / \mathrm{a}^{*}\right) \\
& \mathrm{C}=\left(\left(\mathrm{a}^{*}\right)^{2}+\left(\mathrm{b}^{*}\right)^{2}\right)^{1 / 2} \\
& \Delta \mathrm{E}^{*}=\left(\left(\Delta \mathrm{L}^{*}\right)^{2}+\left(\Delta \mathrm{C}^{*}\right)^{2}+\left(\Delta \mathrm{h}^{*}\right)^{2}\right)^{1 / 2}
\end{aligned}
$$

\subsubsection{Chemical composition}

The moisture, fat, protein, ash and soluble solids contents, and the total acidity and $\mathrm{pH}$ values were determined using the standard AOAC methods 920.151, 991.20, 920.152, 940.26, 932.12, 942.15, and 981.12, respectively (HOROWITZ, 1999). The starch content was determined as described by Southgate (1976).

\subsubsection{Total carotenoid content}

The carotenoids were extracted from 5-g samples according to methods described by Schiedt and Liaaen-Jensen (1995), and Rojas-Garbanzo et al. (2011). The analysis was carried out using a UV-visible spectrophotometer (Shimadzu UV-1700 PharmaSpec, Kyoto, Japan), with a wavelength of $450 \mathrm{~nm}$. The total carotenoid content was expressed as micrograms $(\mu \mathrm{g})$ of $\beta$-carotene equivalents per gram of dry weight (dw).

\subsubsection{Preparing acetone extracts for the determinations of the total polyphenol content and antioxidant capacity}

The extracts were prepared according to Georgé et al. (2005). Samples (3 g) of peach palm fruit were homogenized with $20 \mathrm{~mL}$ of acetone solution (70/30 distilled water) in a $25-\mathrm{mL}$ conical flask covered with aluminium foil. The mixture was then gently stirred for 10 minutes using a magnetic stirrer and ultrasonic bath, and then transferred to a $50-\mathrm{mL}$ volumetric flask by filtering through Whatman No 41 filter paper.

\subsubsection{Total polyphenol content}

The total polyphenols were determined using the modified Folin-Ciocalteu spectrophotometric method as described by Georgé et al. (2005). Gallic acid was used as the standard, and ascorbic acid and reducing sugar interferences were eliminated using OASIS $₫$ cartridges (Waters Corporation, Milford, MA, USA). The absorbance was measured in a UV-visible spectophotometer (Shimadzu UV-1700 PharmaSpec) with a wavelength of $765 \mathrm{~nm}$ against a reagent blank. The polyphenols were quantified using an external calibration curve of gallic acid with a linearity range of $10-80 \mathrm{mg} \mathrm{GAE} / \mathrm{L}$. Good correlation was obtained $(r=0.9996)$, and the concentration of total polyphenols was reported as milligrams $(\mathrm{mg})$ of gallic acid equivalents (GAE) per $100 \mathrm{~g}(\mathrm{dw})$.

\subsubsection{Hydrophilic antioxidant capacity}

The hydrophilic oxygen radical absorbance capacity (H-ORAC) was determined as described by Huang et al. (2002). The assays were carried out using a spectrofluorometer (Synergy HT, BioTek Instruments, Inc, Winooski, VT, USA), with fluorescein as the indicator of peroxyl radical damage. The excitation wavelength was set at $493 \mathrm{~nm}$ and emission wavelength at $515 \mathrm{~nm}$. The H-ORAC was expressed as micromoles ( $\mu \mathrm{mol}$ ) of Trolox equivalents (TE) per dry weight (dw) in grams, using an external calibration curve of Trolox (4.0-32.3 $\mu \mathrm{mol}$ TE/L) with good correlation $\left(r^{2}=0.9993\right)$.

\subsection{Statistical analysis}

To evaluate the physicochemical variability of the peach palm fruits in terms of bioactive compounds and antioxidant capacity, five batches were harvested and three samples from each batch analysed. The study followed a randomized design, with five treatments (five batches). Statistically significant differences amongst the batches were determined using ANOVA $(\alpha=0.05)$ and Tukey's test, using JMP 4.1 software (SAS, Cary, NC, USA). The data was expressed as the mean \pm standard deviation. The general behaviour of the peach palm fruit as a raw material was determined by carrying out a principal component analysis (PCA) using Simca v.13 (MKS Umetrics AB, Sweden).

\section{Results and discussion}

\subsection{Dimensional characteristics}

Table 1 shows the dimensional and some of the physicochemical characteristics of the peach palm fruits available on the Costa Rican market. The differences 
Physicochemical and antioxidant composition of fresh peach palm (Bactris gasipaes Kunth) fruits in Costa Rica

Rojas-Garbanzo, C. et al.

between the lightest and heaviest fruits were more than $140 \%$. Significant differences $(p<0.05)$ were found in the weights of the peach-palm fruits from the Tucurrique 1 (T1) and Tucurrique 2 (T2) batches, whereas the peach palm fruits from Pérez Zeledón $(P Z)$ only varied $(p<0.05)$ with respect to the $P Z 3$ batch. The wide ranges obtained for the dimensional characteristics demonstrated the variability of peach palm fruits (Table 1).

A difference $(p<0.05)$ between batches from the same region even between fruits from the same batch was found, resulting in high standard deviations and confidence intervals. This behaviour was noted in the wide range of weights within and between the batches, probably due to climatic and soil conditions, as well as harvesting time (MORA-URPÍ et al., 1997). Even for fruit from the same batch, the length of the peach palm fruit presented a nearly $100 \%$ variation amongst the different samples. Despite this variability, T2 presented a narrow range of length values, with a difference of $23 \%$ between the shortest and the longest fruits. No significant difference was found between T1 and T2 from the same area (Tucurrique) or between groups PZ1, PZ2 and PZ3 (Pérez Zeledón). These results are in line with those of Blanco et al. (1990) who reported lengths of from 4 to $6 \mathrm{~cm}$ for Costa Rican peach palm fruits. With respect to the width, significant differences $(p<0.05)$ were found between batches from the Tucurrique area (T1 and T2), which were also different from those of PZ2 and PZ3. Regarding the fruits from Pérez Zeledón, PZ1 was significantly different $(p<0.05)$ from the other two batches. PZ2 and PZ3 presented no differences ( $p>0.05)$ and showed similarity to T1. In terms of variability in length, the variability in the width measurement was so big that it caused no difference between the batches. Thus the broad ranges obtained in this study are evidence of the wide variability peach palm fruits present, even in samples from the same area.

\subsection{Chemical characteristics}

As shown in Figure 1, significant differences $(p<0.05)$ were found in the moisture contents of the three batches from Pérez Zeledón (PZ1, PZ2 and PZ3). No variability was found in the moisture content between the batches from Tucurrique, but T1 and T2 were different from PZ1, PZ2 and PZ3. The variability found in this study echoes the results obtained by other authors such as Blanco et al. (1990), who reported values ranging from 36 to $76 \mathrm{~g} / 100 \mathrm{~g}$.

For all the components analysed, only the starch content did not show significant differences ( $p>0.05)$ between batches from the same area and between regions (Figure 1). Other authors such as Blanco et al. (1990) and Jane et al. (1992) have reported starch contents from

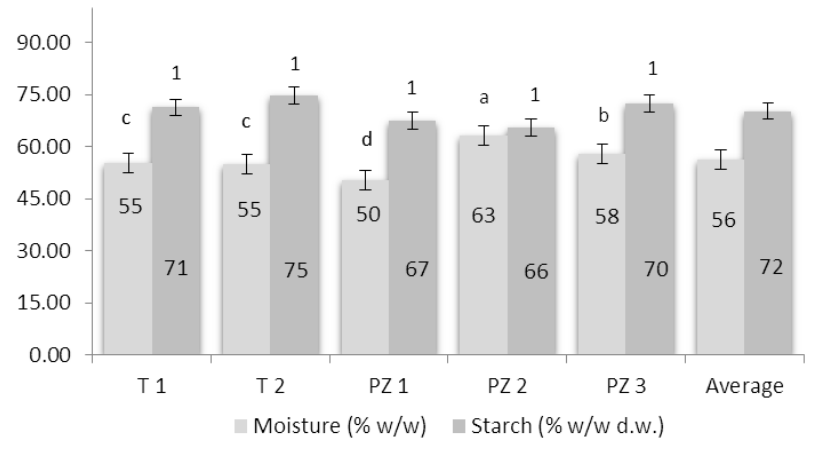

Figure 1. Moisture and starch contents of peach palm fruits commercially available in Costa Rica. $n=3$. Error bars represent the confidence intervals. Different letters or numbers indicate significant differences between batches at $p<0.05$.

Table 1. Variation in the dimensional and physicochemical characteristics of raw peach palm fruits.

\begin{tabular}{|c|c|c|c|c|c|c|c|}
\hline \multirow{2}{*}{\multicolumn{2}{|c|}{$\begin{array}{l}\text { Dimensional and } \\
\text { physicochemical } \\
\text { characteristics }\end{array}$}} & \multicolumn{5}{|c|}{ Batches } & \multirow[b]{2}{*}{ Mean } \\
\hline & & T2 & PZ1 & PZ2 & PZ3 & & \\
\hline \multirow{2}{*}{$\begin{array}{l}\text { Weight } \\
\text { (g) }\end{array}$} & Range & $24-57$ & $35-55$ & $27-55$ & $29-59$ & $32-49$ & $24-59$ \\
\hline & Mean & $37 \pm 8^{a}$ & $45 \pm 5^{b}$ & $42 \pm 8^{b, c}$ & $40 \pm 9^{a, b}$ & $39 \pm 4^{\mathrm{a}, \mathrm{c}}$ & $41 \pm 7$ \\
\hline \multirow{2}{*}{$\begin{array}{l}\text { Length } \\
(\mathrm{cm})\end{array}$} & Range & 3.3-6.0 & $3.7-4.8$ & 3.3-4.9 & $3.2-4.5$ & $3.1-5.0$ & $3.1-6.0$ \\
\hline & Mean & $4.1 \pm 0.5^{a, b}$ & $4.3 \pm 0.3^{a}$ & $4.1 \pm 0.3^{a, b}$ & $3.9 \pm 0.4^{b}$ & $4.1 \pm 0.4^{\mathrm{a}, \mathrm{b}}$ & $4.1 \pm 0.4$ \\
\hline \multirow{2}{*}{$\begin{array}{l}\text { Width } \\
(\mathrm{cm})\end{array}$} & Range & $3.5-4.9$ & $4.2-4.7$ & $3.5-4.5$ & $3.1-4.5$ & $3.4-4.7$ & $3.1-4.9$ \\
\hline & Mean & $4.0 \pm 0.4^{b}$ & $4.4 \pm 0.2^{a}$ & $4.2 \pm 0.3^{b}$ & $3.8 \pm 0.3^{c}$ & $3.8 \pm 0.3^{c}$ & $4.0 \pm 0.4$ \\
\hline \multicolumn{2}{|c|}{ Ash (g/100 g) } & $1.84 \pm 0.04^{\mathrm{a}, \mathrm{c}, \mathrm{d}}$ & $1.70 \pm 0.01^{a, b, d}$ & $1.65 \pm 0.07^{b, d}$ & $1.88 \pm 0.04^{c}$ & $1.69 \pm 0.01^{d}$ & $1.8 \pm 0.1$ \\
\hline \multicolumn{2}{|c|}{ Soluble solids (g/100 g) } & $5.0 \pm 0.1^{a}$ & $5.0 \pm 0.1^{a}$ & $4.4 \pm 0.1^{b}$ & $4.4 \pm 0.1^{b}$ & $4.4 \pm 0.1^{b}$ & $4.6 \pm 0.3$ \\
\hline \multicolumn{2}{|c|}{ Acidity * $(\mathrm{g} / 100 \mathrm{~g})$} & $0.13 \pm 0.03^{a}$ & $0.19 \pm 0.01^{a}$ & $0.35 \pm 0.01^{b}$ & $0.34 \pm 0.02^{\mathrm{b}}$ & $0.17 \pm 0.01^{a}$ & $0.23 \pm 0.06$ \\
\hline \multicolumn{2}{|l|}{$\mathrm{pH}$} & $5.95 \pm 0.01^{\mathrm{a}}$ & $5.91 \pm 0.01^{\mathrm{b}}$ & $4.50 \pm 0.01^{c}$ & $4.92 \pm 0.01^{d}$ & $5.08 \pm 0.01^{e}$ & $5.3 \pm 0.6$ \\
\hline
\end{tabular}

Means in the same line with different letters are significantly different $(p<0.05)$. ${ }^{*}$ Expressed as $\mathrm{g}$ of citric acid equivalents / $100 \mathrm{~g}$. Dimensional characteristics: $n=40$; Physicochemical characteristics: $n=3$. Tucurrique batches: T; Pérez Zeledón batches: PZ. 
64 to $82 \mathrm{~g} / 100 \mathrm{~g}(\mathrm{dw})$. This wide range of values may be due to external physical characteristics such as scratches, gender (with unisexual male or female flowers developing on the rachillae), presence or absence of stripes, as well as weather and soil conditions (MORA-URPÍ et al., 1997). This result is very important given that the types of products that may be developed from peach palm fruit are subject to the starch content (puree, cookies, bread, cake). Standardization of the physicochemical characteristics of the raw material allows for quality standardization of the final product.

The $\mathrm{pH}$ values presented greater variability, with significance differences noted between regions and amongst batches from the same region (Table 1). In terms of acidity, the value for the PZ3 batch was different $(p<0.05)$ from the other batches from Pérez Zeledón, but was similar to that of the fruit from Tucurrique (Table 1).

Protein was the other component which presented low variability. Only one batch varied significantly from the batches within the same region: PZ1 from Pérez Zeledón (Figure 2). The protein contents (Figure 2) were similar to the values reported by Yuyama et al. (2003) for peach palm fruit from three different regions in the Amazon (3.8 to $5.3 \mathrm{~g} / 100 \mathrm{~g} \mathrm{dw}$ ). This could be due to the crop, climatic and soil conditions in that region, which have a great influence on the fruit growth and development (BLANCO et al., 1990). Regardless of the low expectations, the protein content values obtained in this study made peach palm fruit quite interesting. Since it is a fruit, the protein content was not expected to be very high, but Yuyama et al. (2003) reported peach palm fruit as a source of 8 essential amino acids. Even though its amino acid content is less than the minimum daily intake recommended by FDA (2009), it is important to consider this fruit as a source of the daily protein requirements for adults and children. However, a comparison of the daily intake with the input from peach palm fruits can be made after the fruit has

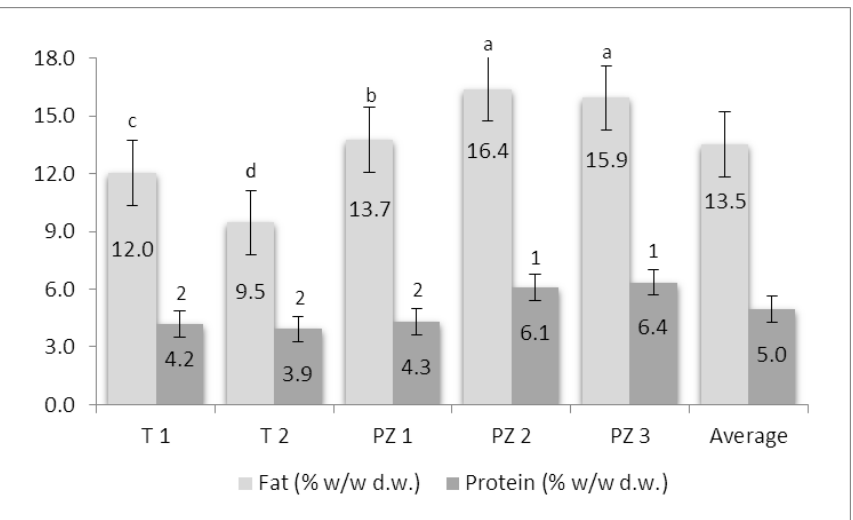

Figure 2. Fat and protein contents of the peach palm fruit commercially available in Costa Rica. $n=3$. Error bars represent confidence interval. Different letters or numbers indicate significant differences amongst batches at $\mathrm{p}<0.05$. been cooked (the traditional preparation method in Costa Rica), because a thermal process is necessary due to the presence of anti-nutritional factors such as lectins, some polyphenols, saponins, oxalic acid, and some amylase and trypsin inhibitors (ROJAS-GARBANZO et al., 2011). It has been reported that the protein content of peach palm fruits is not affected by cooking (30 min in boiling water), the final protein content of cooked peach palm pulp being $5.0 \pm 1.1 \mathrm{~g} / 100 \mathrm{~g} \mathrm{dw}$ (ROJAS-GARBANZO et al., 2012).

The fat content of the peach palm fruits from Tucurrique was lower than that obtained for the fruits from Pérez Zeledón (Figure 2). Different harvest times can influence this component, which could be related to the variations obtained in this study (MORA-URPI et al., 1997). On the other hand, the high fat content of the peach palm fruits from Costa Rica ( 9.5 to $16.4 \% \mathrm{dw}$ ) enhanced the carotenoid bioavailability, since lipids stimulate the absorption of this type of antioxidant and provitamin $A$ compound (RODRÍGUEZ-AMAYA, 1996).

\subsection{Carotenoid contents and colour determination}

The variation in the bioactive compound contents has been studied for many fruits. Normally, climatic or soil conditions can reduce or increase the bioactive compounds such as carotenoids or polyphenols (DRAGOVIC-UZELAC et al., 2007), which are the major contributors to the antioxidant activity of vegetables, fruits and cereals (AJILA et al., 2007).

Since carotenoids are lipophilic compounds, it might be expected that the variability in carotenoid content would be related to the fat content. However, significant differences in the fat contents were not reflected in the carotenoid values. The carotenoid content showed less variation (Figure 3) and no significant differences between batches. Some batches did not vary in terms of carotenoid content $(p>0.05)$ such as T1 and PZ1, from

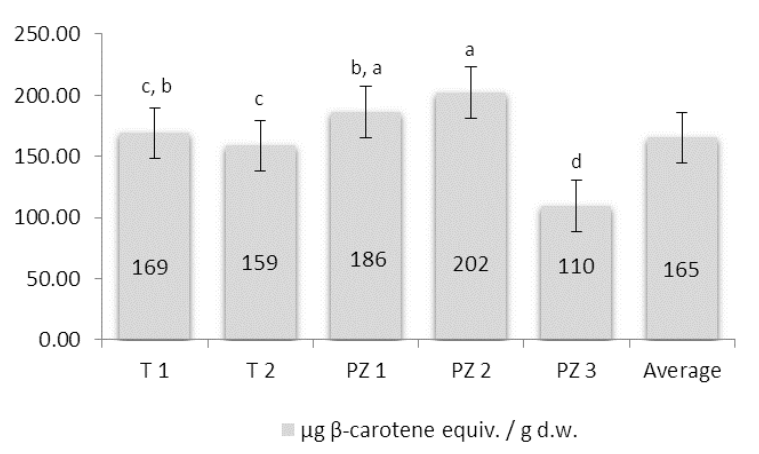

Figure 3. Carotenoid content of peach palm fruit commercially available in Costa Rica $(n=3)$. Errors bars represent confidence interval. Different letters or numbers indicate significant differences amongst batches at $p<0.05$. 
different origins, $\mathrm{T} 1$ and $\mathrm{T} 2$ (Tucurrique), and PZ 1 and $\mathrm{PZ}$ 2 (Pérez Zeledón). Only PZ3 varied significantly $(p<0.05)$ from all the other batches analysed. The extreme values in the range were presented by batches from the same origin (PZ2 and PZ3). Comparing the carotenoid contents of fresh Costa Rican peach palm fruits, the data obtained in the present study were similar to values reported by Rosso and Mercadante (2007) for peach palm fruits from Amazonia (197.66 $\mu \mathrm{g} \beta$-carotene equivalents $/ \mathrm{g}$ fresh weight $(\mathrm{fw}))$. This value is within the range of the carotenoid content obtained in the present study (Figure 3). Compared with other fruit, fresh peach-palm fruit presented a higher carotenoid content than pineapple and papaya, with a carotenoid content of $25.2 \mu \mathrm{g} / \mathrm{g} \mathrm{dw}$ and $106.7 \mu \mathrm{g} / \mathrm{g} \mathrm{dw}$, respectively (KOK; ISHAK, 1991). The carotenoid content of raw Costa Rican peach palm fruit ranged from 46.0 to $94.6 \mathrm{\mu g} / \mathrm{g} \mathrm{fw}$. This content was greater than that reported by Rodríguez-Amaya (1996) for fresh fruits such as mango var. Tommy Atkins $(13 \pm 1 \mu \mathrm{g} / \mathrm{g})$, papaya $(2.5 \pm 1.0 \mu \mathrm{g} / \mathrm{g})$, acerola (26 $\pm 4 \mu \mathrm{g} / \mathrm{g})$ and even raw peach palm from Brazil (22 $\pm 12 \mu \mathrm{g} / \mathrm{g})$. The carotenoid content may be related to the colour parameters. The structure of carotenoids is based on double bonds that are capable of generating colour (orange and red), and compounds with more double bonds generate a more intense colour. In addition, the higher the carotenoid content the higher the values of $a^{*}$ (green-red) and b* (blue-yellow) (BRITTON, 1995).

The presence of carotenoids in peach palm fruit generates coloration that varies from yellow to red in the peel and pulp of the fruit. Table 2 shows the results obtained for the colour parameters of fresh peach palm fruit.

The values for $L^{*}, a^{*}$ and $b^{*}$ were not related to the variation in the carotenoid content of the five batches. This was confirmed by carrying out a correlation analysis, where the value of the correlation between each colour parameter and the carotenoid content was lower than 0.85 . Besides, the fresh peach palm fruit of PZ2 presented the highest carotenoid content, a higher $\mathrm{a}^{*}$ value (stronger red colour), and the lowest $b^{*}$ value (weaker yellow colour). This may be due to a higher composition of carotenoids with a high number of double bonds such as $\beta$-carotene (9 double bonds in the carbon chain) (BRITTON, 1995) and lycopene (11 double bonds) (ROJAS-GARBANZO et al., 2011). This specific carotenoid is also present in a higher proportion in the total carotenoids of the peach palm fruit (ROSSO; MERCADANTE, 2007; ROJAS-GARBANZO et al., 2011). According to Nicoli et al. (1999), as more carotenoids become available, more colour is expressed. This variation depends on the compounds linked inside the macromolecules present in the fruit. The values for each colour parameter were different for each batch (Table 2). In this case, another colour parameter had to be used to compare the variation amongst the samples of peach palm fruits. The total colour difference $\left(\Delta \mathrm{E}^{\star}\right)$ indicates the total expression of colour and is obtained from the $L^{*}, a^{*}$ and $b^{*}$ values (GONNET, 1998). According to this author, the $\Delta \mathrm{E}^{*}$ value must be equal to or greater than 5 to distinguish colour differences between two samples. The $\Delta \mathrm{E}^{\star}$ parameter estimated for the fresh peach palm fruit of $\mathrm{T} 2$ with respect to the other batches, was greater than 5 (Table 3), especially when compared to PZ1, where total colour difference was 11.26. Except for T2, the peach palm fruits from different regions and different harvest times had $\Delta \mathrm{E}^{\star}$ values below 5 (Table 3). This result can be explained by the fact that T2 showed significantly different values for $a^{*}, b^{*}$ and $L^{*}$; the $b^{*}$ value was particularly higher than the other batches by 10 units $(60.51 \pm 0.05)$. The value obtained for $b^{*}$ indicated that the fruit had a more intense shade of yellow as well as presenting the lowest brightness value $\left(\mathrm{L}^{*}=74.7 \pm 0.2\right)$.

\subsection{Total polyphenol content}

The polyphenol contents of the fresh peach palm fruits (Figure 4) presented less variability between batches than the variability shown by the total carotenoid content (Figure 3).

In the case of the carotenoids, three of the five batches presented significant differences ( $p>0.05)$, while the polyphenol content varied $(p<0.05)$ for just two batches. Specifically, PZ2 was different from all the others (Figure 4) and had the highest polyphenol content, while T1, PZ1 and PZ3 were not different ( $p>0.05)$. No difference was found between T2 and PZ1 from the two areas studied, so it could be said that the origin of the peach palm fruits had no influence on the polyphenol content despite the existence of many varieties. Variations in the contents of

Table 2. Variation in the colour parameters of raw peach palm fruit pulp $(n=3)$.

\begin{tabular}{|c|c|c|c|c|c|}
\hline \multirow{2}{*}{ Colour parameters } & \multicolumn{5}{|c|}{ Batches } \\
\hline & T1 & T2 & PZ1 & PZ2 & PZ3 \\
\hline$L^{*}$ & $75.39 \pm 0.01^{a}$ & $74.7 \pm 0.2^{b}$ & $76.3 \pm 0.0^{c}$ & $75.43 \pm 0.03^{a}$ & $75.2 \pm 0.3^{a}$ \\
\hline$a^{*}$ & $16.47 \pm 0.06^{a}$ & $18.9 \pm 0.2^{b}$ & $14.80 \pm 0.06^{c}$ & $18.2 \pm 0.1^{b, d}$ & $17.9 \pm 0.4^{d}$ \\
\hline$b^{*}$ & $52.00 \pm 0.02^{a}$ & $60.51 \pm 0.05^{b}$ & $50.16 \pm 0.05^{a}$ & $50.6 \pm 0.2^{\mathrm{a}}$ & $51.0 \pm 1.1^{\mathrm{a}}$ \\
\hline Hue & $72.41 \pm 0.01^{a}$ & $72.6 \pm 0.2^{\mathrm{a}}$ & $73.56 \pm 0.07^{b}$ & $70.27 \pm 0.02^{c}$ & $70.67 \pm 0.01^{d}$ \\
\hline chroma & $54.5 \pm 0.2^{a}$ & $63.48 \pm 0.01^{b}$ & $52.29 \pm 0.03^{c}$ & $53.8 \pm 0.3^{a, c}$ & $54.0 \pm 1.2^{a, c}$ \\
\hline
\end{tabular}

Means in the same line with different letters are significantly different $(p<0.05)$. Tucurrique: T; Pérez Zeledón: PZ; $n=3$. 
Table 3. Total colour difference between five batches of fresh peach palm fruits in Costa Rica $(n=3)$.

\begin{tabular}{ccccc}
$\begin{array}{c}\text { Total colour } \\
\text { difference }\left(\Delta \mathbf{E}^{\star}\right)\end{array}$ & T2 & PZ1 & PZ2 & PZ3 \\
\hline T1 & $\mathbf{8 . 9 1}$ & 2.63 & 2.16 & 1.72 \\
T2 & -- & $\mathbf{1 1 . 2 6}$ & $\mathbf{9 . 9 6}$ & $\mathbf{9 . 5 8}$ \\
PZ1 & -- & -- & 3.50 & 3.37 \\
PZ2 & -- & -- & -- & 0.51 \\
\hline
\end{tabular}

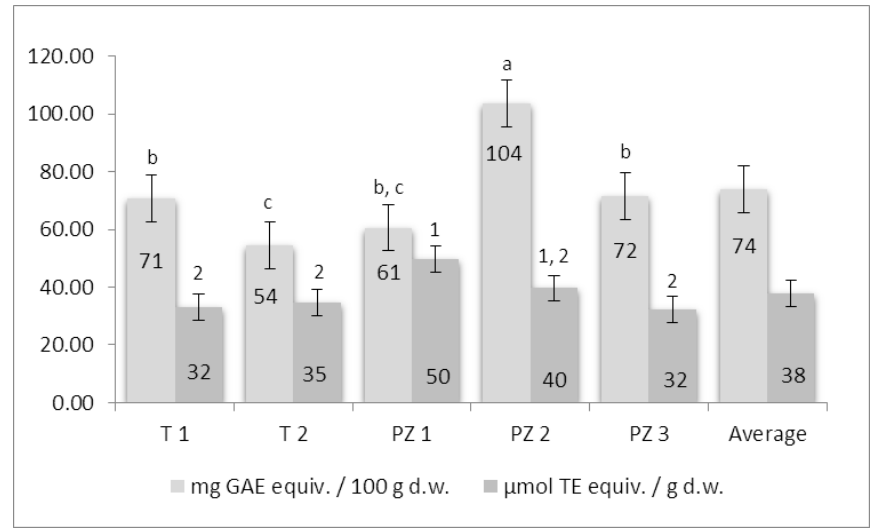

Figure 4. Polyphenol contents and antioxidant activity of peach palm fruits commercially available in Costa Rica $(n=3)$. Error bars represent the confidence interval. Different letters or numbers indicate significant differences between batches at $p<0.05$.

the different batches studied could be due to pre-harvest factors and internal structures of the peach palm plant (MORA-URPÍ et al., 1997). The polyphenol content of fresh Costa Rican peach palm fruit was greater than that reported by Vinson et al. (2001) in melon var. Cantaloupe (25.6 mg GAE/100 g dw) and oranges (40.6 mg GAE/100 g dw). The total polyphenol content for batches PZ1 and PZ2 was equivalent to that found by Vinson et al. (2001) in watermelon (63.8 $\mathrm{mg} \mathrm{GAE} / 100 \mathrm{~g} \mathrm{dw}$ ) and avocado (101.5 mg GAE/100 g dw). Recently, Contreras-Calderón et al. (2011) reported a total polyphenol content for the fresh peach palm fruit from Colombia of $65.7 \mathrm{mg} \mathrm{GAE} / 100 \mathrm{~g} \mathrm{fw}$, higher than the polyphenol content of the peach palm fruits from Costa Rica (38.5 mg GAE/100 fw). Once again, the differences in the polyphenols could be due to the cultivar and the climatic and soil conditions. However, regardless of the origin of the peach palm, its fruit can be considered a source of antioxidants at levels that were not expected to be as high as those for plums, strawberries and blackberries (ISSA et al., 2006).

\subsection{Hydrophilic antioxidant capacity}

The antioxidant capacity of peach palm fruits is due to the presence of compounds such as carotenoids, polyphenols, vitamin $\mathrm{C}$ and of minerals such as selenium and zinc (LETERME et al., 2005). Carotenoids are of a lipophilic nature, while polyphenols, vitamin $\mathrm{C}$, selenium and zinc are hydrophilic antioxidants. The hydrophilic antioxidant capacity of fresh peach palm fruits (Figure 4) was greater than that reported by Wu et al. (2004) for total antioxidant capacity (lipophilic and hydrophilic) of fruits such as melon

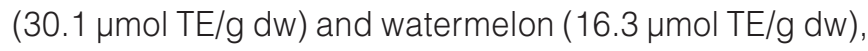
which are other fruit sources of carotenoids like the peach palm fruits. In the case of fat-rich fruits such as avocado, Wu et al. (2004) reported a hydrophilic antioxidant capacity of $48.2 \mu \mathrm{mol}$ TE/g dw, similar to that presented by the peach palm fruits. Regarding the variability in the antioxidant capacity of peach palm fruits (Figure 4), there were significant differences between the batches $\mathrm{T} 1, \mathrm{~T} 2$ and $\mathrm{PZ1}$, and between the latter and PZ3. Batches $T 1, T 2, P Z 2$ and PZ3 did not show significant variation ( $p>0.05$ ), despite their different origins. Other studies have been carried out to measure the peach palm antioxidant capacity, but they cannot be compared with the results of the present study since the methods used (FRAP and ABTS) were different from that used here (ORAC method).

\subsection{Principal component analysis: variability of peach-palm fruit as a raw material}

The principal component analysis was carried out to evaluate the dissimilarity between two different geographical origins and harvest seasons (Figures 5 and 6 ). The geographical origin can be seen on the first component axis, accounting for $95 \%$ of the composition presented by the peach palm fruits. All the properties assessed showed strong impacts on the model. In general, there was no variability in the physicochemical composition of the peach palm fruits amongst the batches studied from the same region. In the case of batches from Pérez Zeledón, there was variability in the composition of one of the batches.

Furthermore, as shown in Figure 6, there was a trend for three sampling groups of components: the first group with variables such as starch, $\mathrm{pH}$, soluble solids, $\mathrm{b}^{*}$ and chroma; the second group including the variables of moisture, fat, protein, ash and phenolic compounds; and the third group including the total carotenoid content, $\mathrm{H}$-ORAC, $\mathrm{L}^{*}$ and acidity. The variable $\mathrm{a}^{*}$ and hue were not assigned to any of the groups. It can be concluded from Figure 6 that the value for $a^{*}$ and the hue would vary from batch to batch. If product quality depends on the variables mentioned in the second group, special attention should be given to these components, since these are the ones that presented significant differences amongst the batches and the selection of the raw material should therefore be very strict. If product quality depends on the variables mentioned in the first group, it could be said that the variability in the physicochemical composition of the commercially available peach palm fruits in Costa Rica and globally is minimal, and could therefore provide raw material that allows for the development of stable 


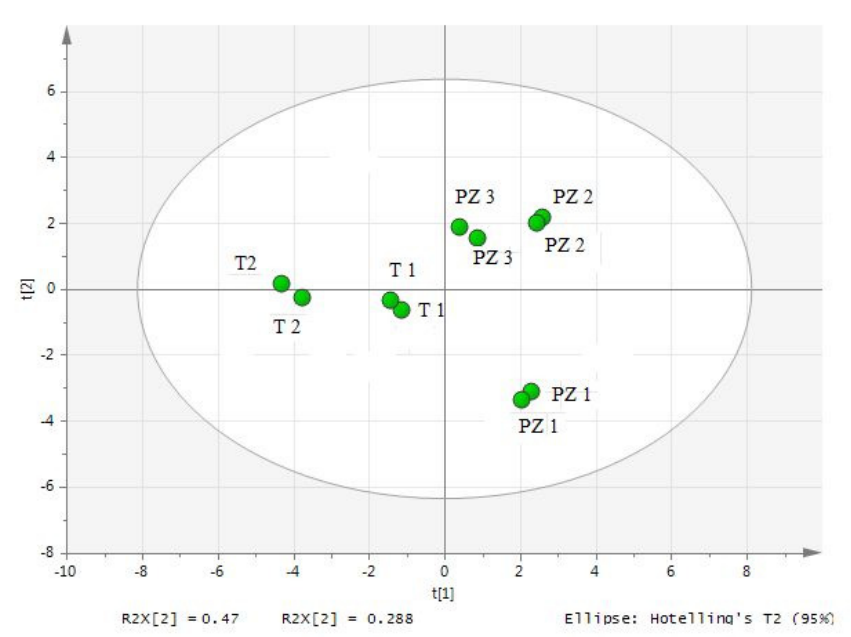

Figure 5. Principal component analysis for the peach palm fruits commercially available in Costa Rica from two different geographic origins.

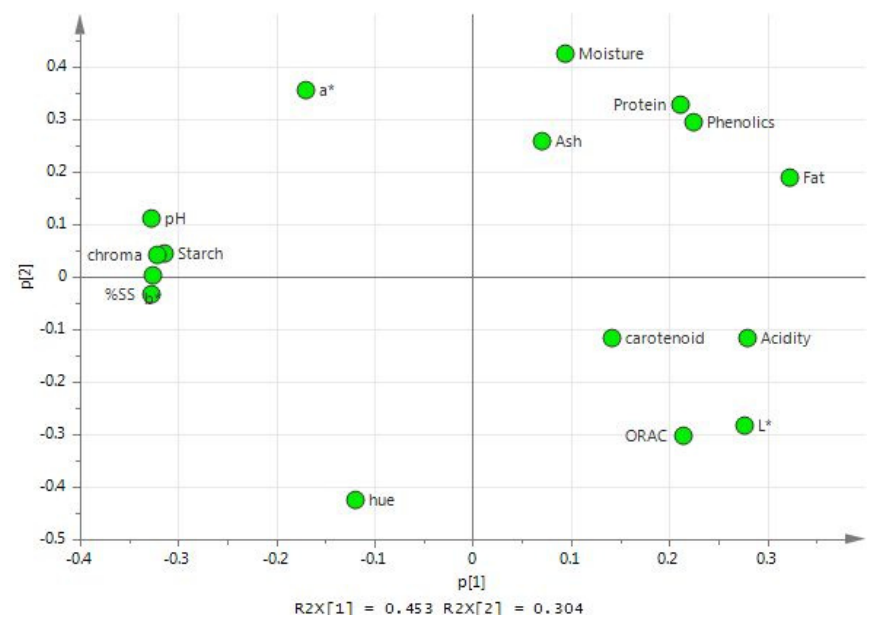

Figure 6. Loading scatter plot of the different properties assessed from different geographical origins and harvesting seasons for peach palm fruits commercially available in Costa Rica.

industrial production, especially for products in which quality depends on the starch content and type.

\section{Conclusions}

As shown in this study, the physicochemical variability amongst fresh peach palm fruits may depend on the component being studied, since each variable studied produced different significant variations amongst the batches. Certain characteristics of fresh peach palm fruit, such as the moisture, fat, starch and protein contents, were not affected by harvest time, and no differences were noted amongst batches from the same area. In addition, despite the significant differences in the total carotenoids, total polyphenol contents and antioxidant capacity found amongst the batches, the results showed that the peach palm fruits commercially available in Costa Rica were a good source of antioxidant compounds, with hydrophilic antioxidant capacity greater than that reported for more traditional fruits. Also, this fruit represents an important alternative for the development of products with an interesting content of antioxidants and provitamin A compounds.

\section{Acknowledgements}

This work was supported financially by the European Union (PAVUC project, INCO no. 015279) and the Vice Rector for Research of the University of Costa Rica (Project VI 735-A8-163).

\section{References}

ABUSHITA, A.; DAOOD, H.; BIACS, P. Change in carotenoids and antioxidant vitamins in tomato as a function of varietal and technological factors. Journal of Agricultural and Food Chemistry, Washington, v. 48, n. 6, p. 2075-2081, 2000. http:// dx.doi.org/10.1021/jf990715p. PMid:10888501.

AJILA, C. M.; NAIDU, K. A.; BHAT, S. G.; PRASADA-RAO, U. J. S. Bioactive compounds and antioxidant potential of mango peel extract. Food Chemistry, New York, v. 105, n. 3, p. 982-988, 2007. http://dx.doi.org/10.1016/j.foodchem.2007.04.052.

BLANCO, A.; LOWERY, M.; MONTERO, M.; MORA-URPÍ, J.; ROJAS, M. El pejibaye: su uso en la alimentación humana. San José: Instituto Costarricense de Investigación y Enseñanza en Nutrición y Salud, 1990. p. 1-7.

BRITTON, G. Structure and properties of carotenoids in relation to function. Faseb Journal, Bethesda, v. 9, n. 15, p. 1551-1558, 1995. PMid:8529834.

CONTRERAS-CALDERÓN, J.; CALDERÓN-JAIMES, L.; GUERRAHERNÁNDEZ, E.; GARCÍA-VILLANOVA, B. Antioxidant capacity, phenolic content and vitamin $C$ in pulp, peel and seed from 24 exotic fruits from Colombia. Food Research International, Toronto, v. 44, n. 7, p. 2047-2053, 2011. http://dx.doi.org/10.1016/j. foodres.2010.11.003.

DIBARI, F. Ecological flour with pupunha. Intermediate Technology Food Chain, Rugby, v. 20, p. 7-10, 1997.

DRAGOVIC-UZELAC, V.; LEVAJ, B.; MRKIC, V.; BURSAC, D.; BORAS, M. The content of polyphenols and carotenoids in three apricot cultivars depending on stage of maturity and geographical region. Food Chemistry, New York, v. 102, n. 3, p. 966-975, 2007. http://dx.doi.org/10.1016/j.foodchem.2006.04.001.

DUTRA, A. S.; FURTADO, A. A. L.; PACHECO, S.; OIANO NETO, J. Efeito do tratamento térmico na concentração de carotenoides, compostos fenólicos, ácido ascórbico e capacidade antioxidante do suco de tangerina murcote. Brazilian Journal of Food Technology, Campinas, v. 15, n. 3, p. 198-207, 2012. http:// dx.doi.org/10.1590/S1981-67232012005000012. 
Physicochemical and antioxidant composition of fresh peach palm (Bactris gasipaes Kunth) fruits in Costa Rica Rojas-Garbanzo, C. et al.

GEORGÉ, S.; BRAT, P.; ALTER, P.; AMIOT, M. Rapid determination of polyphenols and vitamin $C$ in plant-derived products. Journal of Agricultural and Food Chemistry, Washington, v. 53, n. 5, p. 1370-1373, 2005. http://dx.doi.org/10.1021/jf048396b. PMid:15740008

GONNET, J. Colour effects of copigmentation of anthocyanins revisited - I: a colourmetric definition using the CIELAB scale. Food Chemistry, New York, v. 63, n. 3, p. 409-441, 1998. http:// dx.doi.org/10.1016/S0308-8146(98)00053-3.

HOROWITZ, H. (Ed.). Official methods of analysis of the Association of Official Analytical Chemists. 16 ${ }^{\text {th }}$. ed. Gaithersburg: AOAC, 1999. v. 1.

HUANG, D.; OU, B.; HAMPSCH-WOODILL, M.; FLANAGAN, J.; PRIOR, R. High-throughput assay of oxygen radical absorbance capacity (ORAC) using a multichannel liquid handing system coupled with a micro-plate fluorescence reader in 96-well format. Journal of Agricultural and Food Chemistry, Washington, v. 50 , n. 16, p. 4437-4444, 2002. http://dx.doi.org/10.1021/jf0201529. PMid:12137457

ISSA, A. Y.; VOLATE, S. R.; WARGOVICH, M. J. The role of phytochemicals in inhibition of cancer and inflammation: New directions and perspectives. Journal of Food Composition and Analysis, Oxford, v. 19, n. 5, p. 405-419, 2006. http://dx.doi. org/10.1016/j.jfca.2006.02.009.

JANE, J.; SHEN, L.; AGUILAR, F. Characterization of pejibaye starch. Cereal Chemistry, Minneapolis, v. 69, p. 96-100, 1992.

KOK, N.; ISHAK, S. Carotenoid and anthocyanin contents of papaya and pineapple: influence of blanching and drying treatments. Food Chemistry, New York, v. 39, p. 175-185, 1991.

LETERME, P.; GARCÍA, M. F.; LONDOÑO, A.; ROJAS, M.; BULDGEN, A.; SOUFFRANT, W. Chemical composition and nutritive value of peach palm (Bactris gasipaes Kunth) in rats. Journal of the Science of Food and Agriculture, London, v. 85, n. 9, p. 1505-1512, 2005. http://dx.doi.org/10.1002/jsfa.2146.

MORA-URPÍ, J.; WEBER, J.; CLEMENT, C. Peach Palm, Bactris gasipaes Kunth: promoting the conservation and use of underutilized and neglected crops. Rome: Institute of Plant Genetic and Crop Plant Research, Gatersleben International Plan Genetic Resources Institute, 1997. 83 p.

NICOLI, M. C.; ANESE, M.; PARPINEL, M. Influence of processing on the antioxidant properties of fruit and vegetables. Trends on Food Science and Technology, Cambridge, v. 10, n. 3, p. 94-100, 1999. http://dx.doi.org/10.1016/S0924-2244(99)00023-0.

PÉREZ-MATEOS, M.; BRAVO, L.; GOYA, L.; GÓMEZ-GUILLÉN, C.; MONTERO, P. Quercetin properties as a functional ingredient in omega-3-enriched fish gels fed to rats. Journal of the Science of Food and Agricultural, London, v. 85, n. 10, p. 1651-1659, 2005. http://dx.doi.org/10.1002/jsfa.2164.

RODRÍGUEZ-AMAYA, D. Assessment of the provitamin A contents of foods: the brazilian experince. Journal of Food Composition and Analysis, Oxford, v. 9, n. 3, p. 196-230, 1996. http://dx.doi. org/10.1006/jfca.1996.0028.

ROJAS-GARBANZO, C.; PÉREZ, A. M.; BUSTOS-CARMONA, J.; VAILLANT, F. Identification and quantification of carotenoids by HPLC-DAD during the process of peach palm (Bactris gasipaes H.B.K.) flour. Food Research International, Toronto, v. 44, n. 7, p. 2377-2384, 2011. http://dx.doi.org/10.1016/j.foodres.2011.02.045.

ROJAS-GARBANZO, C.; PÉREZ, A. M.; PINEDA, M. L.; VAILLANT, F. Major physicochemical and antioxidant changes during peach palm (Bactris gasipaes H.B.K.) flour processing. Fruits Les Ulis Cedex A, Paris, v. 67, p. 415-427, 2012.

ROSSO, V. V.; MERCADANTE, A. Z. Identification and quantification of carotenoids, by HPLC-PDA-MS/MS, from Amazonian fruits. Journal of Agricultural and Food Chemistry, Washington, v. 55, n. 13, p. 5062-5072, 2007. http://dx.doi.org/10.1021/jf0705421. PMid: 17530774 .

SÁ, M.; RODRÍGUEZ-AMAYA, D. Carotenoid composition of cooked green vegetables from restaurants. Food Chemistry, New York, v. 83, n. 4, p. 595-600, 2003. http://dx.doi.org/10.1016/ S0308-8146(03)00227-9.

SCHIEDT, K.; LIAAEN-JENSEN, S. Isolation and analysis. In: BRITTON, G.; LIAAEN-JENSEN, S.; PFANDER, H. (Ed.). Carotenoids: isolation and analysis. Basel: Birkhäuser Verlag, 1995. p. 102-107. v. 1 A.

SOUTHGATE, D. A. Determination of food carbohydrates. In: SOUTHGATE, D. A. Selected methods. London: Applied Science Publishers, 1976. p. 1-4. chap. 8.

TRACY, M. Harina de pejibaye, una opción prometedora. Boletín Informativo RETADAR, San José, v. 23, p. 3, 1996.

U.S. FOOD AND DRUG ADMINISTRATION - FDA. 21 CFR 101.9 nutrition labeling of food: DRAFt 2011-04-28. Silver Spring: FDA, 2009. Available at: <http://www.accessdata.fda.gov/ scripts/cdrh/cfdocs/cfcfr/CFRSearch.cfm?fr=101.9>. Accessed on: 6 oct. 2014 .

VINSON, J.; SU, X.; ZUBIK, L.; BOSE, P. Phenol antioxidant quantity and quality in foods: fruits. Journal of Agricultural and Food Chemistry, Washington, v. 49, n. 11, p. 5315-5321, 2001. http://dx.doi.org/10.1021/jf0009293. PMid:11714322.

WU, X.; BEECHER, G.; HOLDEN, J.; HAYTOWITZ, D.; GEBHARDT, S.; PRIOR, R. Lipophilic and hydrophilic antioxidant capacities of common foods in the United States. Journal of Agricultural and Food Chemistry, Washington, v. 52, n. 12, p. 4026-4037, 2004. http://dx.doi.org/10.1021/jf049696w. PMid:15186133.

YUYAMA, L.; AGUIAR, J.; YUYAMA, K.; CLEMENT, C.; MACEDO, S.; FÁVARO, D.; AFONSO, C.; VASCONCELLOS, M.; PIMENTEL, S.; BADOLATO, E.; VANNUCCHI, H. Chemical composition of the fruit mesocarp of three peach palm (Bactris gasipaes) populations grown in Central Amazonia, Brazil. International Journal of Food Sciences and Nutrition, London, v. 54, n. 1, p. 49-56, 2003. PMid:12701237. 